\title{
A business model canvas for crowdfunding platform: case study of crowdfunding platforms in Malaysia
}

\author{
Muhammad Hakim Bin Nadir ${ }^{1}$, Syaripah Ruzaini Syed Aris², Norjansalika Janom ${ }^{3}$, Fauziah Ahmad ${ }^{4}$, \\ Noor Habibah Arshad ${ }^{5}$, Nor Shahniza Kamal Bashah ${ }^{6}$ \\ ${ }^{1}$ Jouska Enterprise, Malaysia \\ ${ }^{2,3,4,5,6}$ Faculty of Computer and Mathematical Sciences, Universiti Teknologi MARA, Malaysia
}

\begin{tabular}{l}
\hline Article Info \\
\hline Article history: \\
Received Oct 2, 2019 \\
Revised Dec 4, 2019 \\
Accepted Dec 18, 2019 \\
\hline
\end{tabular}

\section{Keywords:}

Business model canvas

Business model elements

Crowdfunding

Entrepreneur

Funder

\begin{abstract}
Crowdfunding allows entrepreneurs raise fund to help subsidizing their project. In other country, crowdfunding platform has become famous. In the contrary, it is yet to be trend in Malaysia. Financing using internet still irrelevant among Malaysian citizen. Without a proper guideline and strong crowdfunding platform based in Malaysia as a benchmark, it is hard to convince entrepreneurs and funders to consider crowdfunding as an option to fund a project. This research thus proposed business model canvas which can be applied by the crowdfunding platform organizations to manage their business and operation more efficiently. Case study method has been employed with two techniques of data collection: interview and document review. Two crowdfunding platforms based in Malaysia participated in the case study. The findings show that both crowdfunding platforms have fundamental business model elements that made of a solid foundation as a crowdfunding platform. These results offer insight into crowdfunding environment and how it links to another necessary part of business for it to function as a successful business. Nine building blocks fits well in the crowdfunding platform business model elements namely partner network, core competency, key resources, value proposition, customer relationship, distribution channel, customer segments, cost structure and revenue stream. Interestingly, the findings revealed another imperative element that should be part of the canvas: risk management.
\end{abstract}

Copyright $(0) 2020$ Institute of Advanced Engineering and Science. All rights reserved.

\section{Corresponding Author:}

Syaripah Ruzaini Syed Aris,

Faculty of Computer and Mathematical Sciences,

Universiti Teknologi MARA,

40000 Shah Alam, Selangor, Malaysia.

Email: ruzaini@fskm.uitm.edu.my

\section{INTRODUCTION}

One of the issues that entrepreneurs face at the very beginning of their entrepreneurial activity is to draw outside capital, given the lack of collateral and sufficient money flows and the presence of significant information asymmetry with investors [1]. Typically, financial specialists exist for larger amounts and measures of capital such as banks, and business angels. Thus, entrepreneurs which requires small amount of capital have to rely on family, friends, and personal savings. With the advent of crowdfunding ideas, entrepreneurs can now rely on crowdfunding to acquire fund for their projects. Crowdfunding is subsidizing or financing a project or a venture by a group of individuals rather than professional parties. Normally, crowdfunding mode of communication is through the web 2.0. This innovation requires new business model which could be used to portray the key components of complete and comprehensive crowdfunding environment. 
The acceptance rate of crowdfunding is low and trustworthiness of the crowdfunding platform is not visible [2]. Crowdfunding structure is also still unclear [3]. Without clear business model, the success of crowdfunding is not guarantee. It is required as a proper guideline for the organization to run its operation while minimizing risks. Since crowdfunding is relatively new in terms of its technological usage and it exists in an uncertain economic environment, new business model is required to make sure the business process can be clearly and effectively implemented. [4] stated that business environment with various discipline, including Information System, marketing and operationalization requires to have a comprehensive business model that are inclusive. This research thus contributes towards the development of business model canvas for crowdfunding platform by adopting case study technique.

\section{LITERATURE REVIEW}

The literature review will be discussing on the business model and crowdfunding. The discussion will be revolved around the definition of the terminology, the main elements and different types for both areas.

Business model can be defined as an abstract portray of the business rational of an organization [5]. It comprehends the business logic as abstract conceptual of the way a company makes profits, what it offers, to whom it offers and how it can achieve this. At the most basic level, the business model is defined exclusively as organization's economic model. It includes revenue sources, pricing methodologies, cost structures, margins, and expected volumes [6]. In [7] describe business model as a conceptual tool that contains a set of elements and their relationships and allows expressing the business logic of a specific firm. It is a description of the value a company offers to one or several segments of customers and of the architecture of the firm and its network of partners for creating, marketing, and delivering this value and relationship capital, to generate profitable and sustainable revenue streams. Table 1 highlight the definition of business model as adapted from [8].

Table 1. Definitions of Business Models

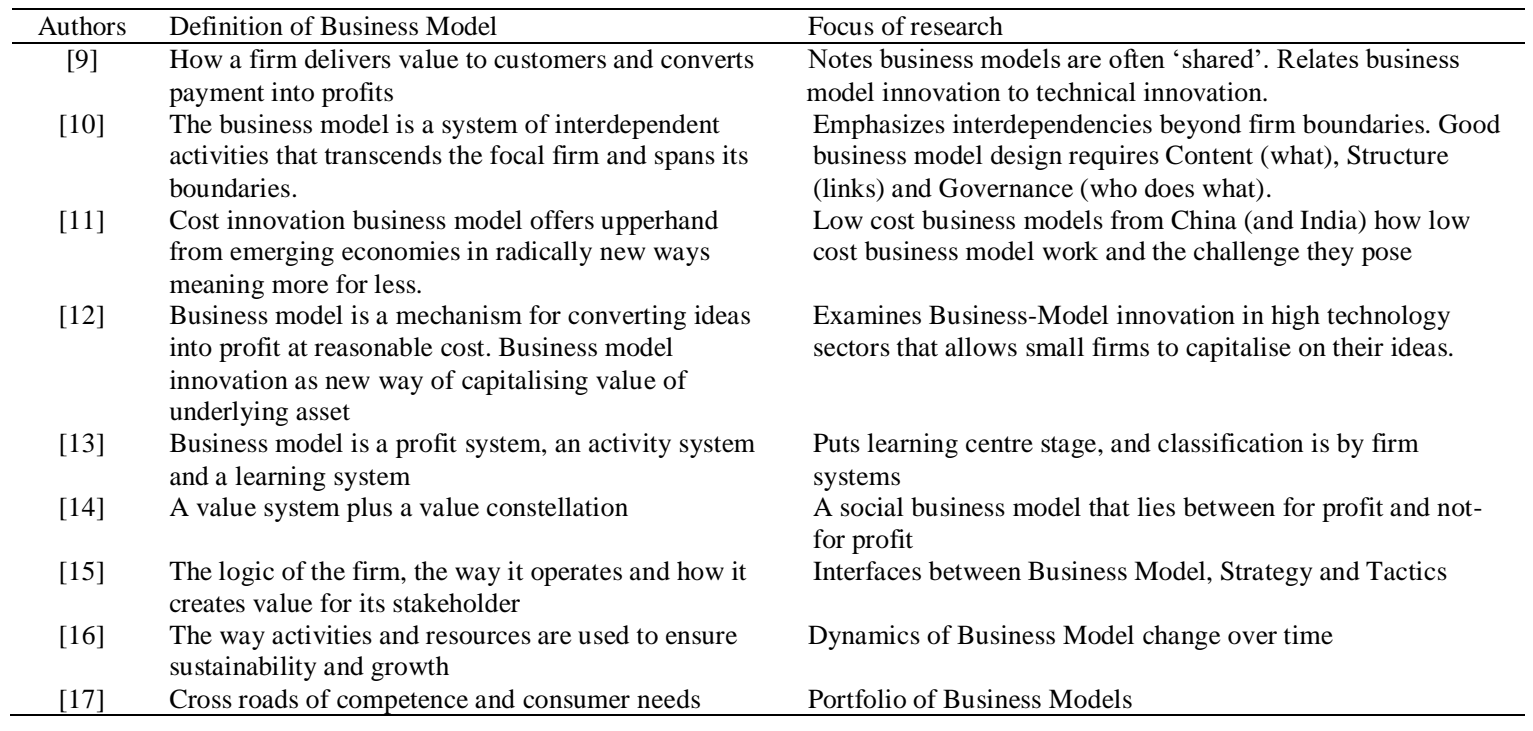

Business models have substantially evolved since the late 1990s. Throughout the years, business models reach its maturity. One of the key drivers behind business model evolution is viewed as technologically innovative and progress enabling ubiquitous communications and increasingly cheap approaches to pass on rich amounts of information [9]. In [18], mentioned that the success of businesses will depends on the ability to take advantage of technological shifts to innovate and enhance in their business models, and eventually to compete differently. The business models keep on changing to adapt the business environment also to provide efficiency to organization and provide value to consumer.

In [19], allude that business model design as the design of a focal firm's set of boundary-spanning transactions with outer parties. From their perspectives, the relationships between focal firm performance and business model design configuration can be observed by looking at two different effects: the total value creation potential of the business model design and the focal firm's ability to appropriate that value. 
They also highlighted the importance of business model as practical strategy which ensure performance and success of an organization. This somehow expresses the imperative of having business model for any organization.

Crowdfunding transactions are facilitated through the internet-based crowdfunding platforms that provide a convenient way for all the exchange of funds [20]. In [21], define crowdfunding as an instrument of raising fund or collecting money from public through online portals to finance both commercial and social projects. In [22] also stated similar definition of crowdfunding where he stated crowdfunding as an open call, most done through Internet, for the provision of financial resources either in the form of donation or in exchange for future product or some reward to support the initiatives for specific purposes. Based on [3], there are five types of crowdfunding namely:

a) Donation: This is a campaign, which calls for public donation. The crowd will draw up monetary gifts (i.e. donations) towards a charity or public institution/organization for some good causes.

b) Reward: It is called a reward-based crowdfunding because those who participate will receive some kind of incentives or rewards. Specifically, a campaign to fund the project is drawn, and in return, the funders are promised to be rewarded with the products or the limited-edition version of the products or any other appropriate gifts.

c) Crowdsourcing: This refers to some start-up projects that may require collective ideas, skills and expertise to develop new products or project. These sources could come internally or externally, and a person who contributes most maybe given equity in the project. Three key players in crowdsourcing are job provider, platforms and digital workers [23]. This type of crowdfunding can also aid the low-income community to uplift their lifestyle through completing task posted via the crowdsourcing platforms $[24,25]$.

d) Equity: This type of crowdfunding offers the funders the ownership of the company. By funding the startups, they are promised the ordinary shares of the newly formed company. In [26] define equity crowdfunding as a method of raising fund by selling a specified amount of equity to a group of small investors through online platforms. These ordinary shares allow the funder's equal right in the company, as any common shareholders would have.

e) Peer-to-Peer Lending (P2P): This mechanism relates to the lending of money through IT platforms. The crowd invests in the startup of a project in return for interest payment. Collecting the money from the crowd who want to participate raises the amount needed. They are promised a return on the capital invested alongside with interest payment at maturity

Crowdfunding have three parties involve; the owner or the founder who proposes the idea or the project, the funders or the supporters who trust the project idea and willing to fund the project, and the platform, which brings the entrepreneurs and the funders together in order to achieve the objectives of the project. The platform plays a very significant role as it is intermediaries between these two parties [3]. There are many crowdfunding platforms, which have proven their capabilities to provide funds to support finance of the new projects. This attribute has expanded, not only providing capital for businesses, but also for social projects [21]. The crowdfunding platforms in Malaysia have been growing rapidly since 2012 . Among widely known crowdfunding platform in Malaysia are Mystartw, PitchIn, Skolafund and Ata-Plus.

\section{METHODOLOGY}

This research adopts case study methods. Two organizations participated in the case study which will be acknowledged as Organization A and Organization B. Interview and documents review were employed as data collection technique. In total, five respondents were interviewed; three from Organization A and 2 from Organization B. For the interview session, semi-structured questions were asked with regards to the following concerns; the organization background, the practices of crowdfunding and the business elements in making crowdfunding a success business.

After the interviews have been successfully conducted, the researchers continuous with document review process. In this phase, the researchers review the documents such as project pitching form, company statement history and crowdfunding procedure and implementation process. This is to get a better and clear picture of how crowdfunding works and its associated process.

All information acquired from interview and documents review technique was analyzed using content analysis technique. The Business Model Canvas was then proposed using business-model planning tool designed by [7]. The canvas consisted of nine building blocks namely value proposition, customer segments, channels (to reach customers), customer relationships, revenue streams, key resources, key partners, key activities, and cost structure. Interestingly, after data analysis, there is one more segment which is also imperative to be included: risk management. The detail description of the analysis is described in the next section. 


\section{RESULTS AND DISCUSSION}

The analysis and discussion will be divided into two sections: the crowdfunding practices and the Business Model Canvas development. The detail description of the results is as follows.

\subsection{The Crowdfunding Practices}

Organization A and Organization B started their crowdfunding initiative in 2012 and 2016 respectively. The two organizations participated in the case study is based on different types of crowdfunding platform. Organization A specialize in reward-based meanwhile Organization B specialize in equity-based crowdfunding. The types of the platform are crucial to be highlighted as the execution of business operation would be different.

It can be concluded that both organizations have three main phases in crowdfunding activities: pre-launch, launch and post-launch. Both organizations require the entrepreneurs to submit their proposal online using their platform. They will then evaluate the proposal. Organization B added that they have two level of screening; Level 1 is to check the credibility of the entrepreneur by checking their background diligently, meanwhile Level 2 is conducted to checks their business planning and future plan. This is to make sure that they will sustain in the future and not using this platform as a gateway to receive easy money.

During launch phase, both organizations stated that the entrepreneurs will start to market their project to the public. Since proper marketing plan makes a huge difference in the result, entrepreneur will promote their products in many ways as possible including via new media and traditional ways. Both organizations stated their willingness to help the entrepreneur whenever their assistance is required.

Post-launch phase demonstrates different activities due to different focus of the platform. Organization A stated that they will provide all the necessary documents and statements within a week after project ended. The money will be transferred to the entrepreneur after deducting $10 \%$ service charge. The entrepreneur will continue with project completion and reward the funder afterwards. On the other hand, the post-launch activities for Organization B are quite different. Third escrow fund account will be established and they will be responsible to collect the fund from the investors until it reaches $100 \%$ of the funding target. If the fund does not achieve $100 \%$ target within the stipulated time period, the investment will be cancelled and the fund will be returned to the investors. If it is successfully collected, Organization B provides the platform where the entrepreneur can update the progress of the projects to the investors.

\subsection{The Business Model Canvas}

The Business Model Canvas (BMC) is a strategic management tool to define and communicate a business idea or concept. It is a one-page document which works through the fundamental elements of a business or product, structuring an idea in a coherent way [7]. Figure 1 shows the business model canvas for crowdfunding platforms in Malaysia compiled from two organizations participated in the research. There is additional component to this BMC, which is risk management that covers some area of risks in performing the crowdfunding business. The proposed BMC provide a comprehensive and inclusive business model which will lead to a clear and effective implementation of crowdfuncding. The following discuss the BMC as shown in Figure 1 in detail.

\subsubsection{Value Propositions}

Value propositions can be described as services and value-added activities delivered by a crowdfunding company to fulfil entrepreneur needs and value to customers.

a) Entrepreneur: Accessibility of funding to everyone-using crowdfunding platform, entrepreneur can have the accessibility of crowdfunding services. Almost anyone within the reach of the crowdfunding platform is viable to become entrepreneur and have similar chance to be funded by investors. Crowdfunding builds a rapid fan-base of customers who like and believe in the project so much that they are willing to pre-pay for the campaign.

b) Funders: Transparent funding-Crowdfunding provide the platform for funders who likes new inventions and it gives huge interest to them as they seeking interesting products and projects. These supporters put front their money in the start-up of a small business, they received reward either as a gift, tangible reward or company shares. The transparent means the funders do not have to dive headfirst into the project or investment. Instead, they have the option to collect as much insight beforehand as they like and make the decision from there. Thus, they are the one who help the development of entrepreneurs to grow. They also provide the platform to allows the entrepreneurs to updates their projects frequently.

c) Funders: Early Involvement in Projects-Once early adopters vet and buy into entrepreneur's idea, others are more likely to follow suit. Involvement by supporters which considered as loyal customer can improve the overall company improvement. Besides that, social proof is translated into traction. 
This perspective could make an early involvement in projects or growing companies become competitive and have real feedback from customers.

d) Beneficial Gain-Crowdfunding works in a way as a convenient platform, low cost, clear and fair funding process. It is also seen as a value proposition for entrepreneurs as well as funders, which adds value by facilitating crowdfunding process on online platform. On the same page, with the use of this platform, many innovative and value-added services have become possible that were unlikely to be imagined using traditional fund-raising method. This scenario allows all actors in crowdfunding activities to receives numerous benefits; entrepreneur gets to be funded to proceed with their project, funders will receive rewards for their funding activities and the platforms receives trust from these activities. This research supports a finding by [27] which stated that platforms must be compelling to as part of its value proposition

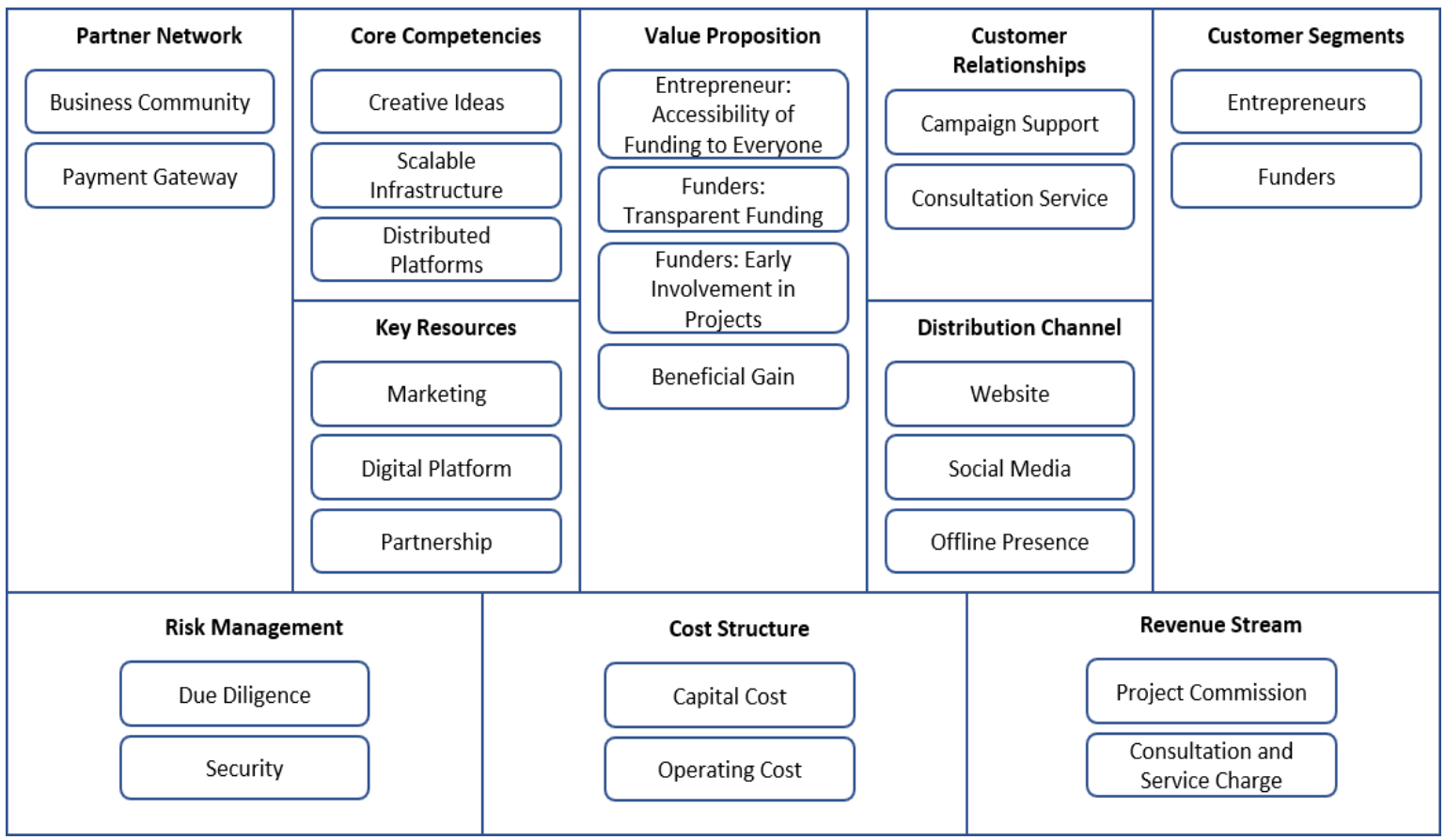

Figure 1. Business model canvas for crowdfunding platform

\subsubsection{Customer Segments}

Customer segment can be defined as the type of customers that a crowdfunding platform wants to address and attract by offering value propositions. In general, there are two types of independent customers for crowdfunding platform, which are entrepreneur and funders.

a) Entrepreneurs - Crowdfunding platforms let entrepreneur raise money from an engaged community of supporters and investors while maintaining company in control. Furthermore, crowdfunding gives entrepreneur exposure to a passionate group of early adopters who are looking to invest in the next big thing, plus access to tools entrepreneur can use to grow the business. Entrepreneur can be the creator, small business, or non-profit organization.

b) Funders - Another customer segment is funders. They are the group of people who have same compelling interest towards a project, who lend money to entrepreneurs' project. The change in product towards improvements and innovative attracts more funders. The entrepreneurs take on the role of being someone who provides golden projects, while funders find project they are interested with and fund it. Most of citizens in Malaysia are getting exposure to crowdfunding. The number of both entrepreneur and funders is expected to growth in future.

\subsubsection{Distribution Channels}

Distribution channels describe how the crowdfunding platform gets in touch with its customers and delivers information to them. The following is the channels currently being used as distribution channels in crowdfunding. 
a) Website-Being a full technology web-based company, the crowdfunding platforms' website (landing page) is crucial. In terms of technology, what it needed is to offer the service of crowdfunding via website that contains everything about the company, guideline, as well as the launched project. There are several ways of crowdfunding platform use to distribute the news such as using blogs for people who loves to read. Usually, the blog will be within the domain website of the company.

b) Social Media-With nearly half of the world's population using social media platforms, it is a natural place to reach new and highly targeted potential funders. Social media such as Facebook can act as a marketing channel that really make a big different in company's engagement and content marketing for soft selling. The ability to create real human connection is another key benefit of social media for business.

c) Offline Presence-Subsequently, other way to target specific segments and reach funders is through direct sales force, which is an offline event. Many crowdfunding platforms join events and give consultation about crowdfunding to public to attract more people to participate in crowdfunding. For entrepreneur, the amount of capital a project raises from the funders can be seen as an indicator of how well the market responds to the entrepreneur's idea. Another aspect of the social relationship is the power of word-of-mouth. Most of entrepreneur and funders discover crowdfunding platforms through friends, family and others.

\subsubsection{Customer Relationships}

Customer relationships refer to the relationship that the crowdfunding platform build and maintains with its customers. The customer relationship is:

a) Campaign Support-The crowdfunding platforms provide support for campaign launch (website). The platforms also provide continuous support to both entrepreneurs and funders. This can be considered as the lifeblood of a company's business activity.

b) Consultation Service-Crowdfunding platforms provide consultation and gives extra services to support entrepreneur. Business advice services may be recognized as golden piece of work that may help the entrepreneurs to escape difficulty in doing the crowdfunding campaign. For example, an application form in crowdfunding platform may recommend a guideline in making company pitching for themselves.

\subsubsection{Core Competency}

The main competency of a platform is to always have something creative ideas to the market. Enabling new features or new ways of doing something would gain popularity and make things interesting. Besides that, crowdfunding platform requires scalable infrastructures and distributed platforms. The platforms will then be specialized niche players or have large benefits from outside partnership. Also, as the crowdfunding platform goes loud, the ability to adapt to the increasing number of users could be in check. Different types of platforms lead to their specialty and for some, this allow fundraising to be completed rapidly.

\subsubsection{Partner Network}

Partnership refers to the voluntarily initiated cooperative agreement of a company with other companies in order to carry out activities related to value propositions. In Malaysia, the partner network for crowdfunding platform includes:

a) Business Community-Crowdfunding companies work with other companies for marketing and sales support purposes. They work together for cross-promotional, security and regulations and branding purposes to allow for better crowdfunding implementation. The positive values instill by this business community helps in increasing the reputation of crowdfunding platforms while allowing them to provide better and efficient service to their customer segments.

b) Payment Gateway-In digital company, usually they form a partnership with payment gateway and website services company. By partnership, business process of crowdfunding could be more efficient and secure. However, equity crowdfunding companies may need to develop strong partnerships for the acquisition of data. In some cases, the agreement for data with Security Commission is difficult to achieve. On the other hand, reward-based crowdfunding platform does not require such thing to run the business.

\subsubsection{Key Resources}

Key resources describe the arrangement of activities and resources. The three main activities for crowdfunding platform are as follows:

a) Marketing-Once the proposal has been reviewed and approved, crowdfunding platform will help to market the project through their digital platform. 
b) Digital Platform-Considered as in-house capabilities, this resource is ultimately important to promote their products as well as services offered and as a platform of communication between their customers and partners.

c) Partnership-In ability to create more establish environment, crowdfunding platform continuously finding and establishing partnership with various business community.

\subsubsection{Cost Structure}

Cost structure describes the costs incurred by crowdfunding platform company for delivering value propositions to its customers and doing all other business activities such as establishing partner relationships and marketing. The cost is stated below:

a) Capital cost-Capital cost can be considered as low barrier of entry in crowdfunding industry. The cost is required for the infrastructure as they need a place for their operation.

b) Operating cost-These costs include costs of acquiring and maintaining data centers (e.g., costs of servers, electricity, cooling, and the use of cloud services) and developing and maintaining the platforms. In some cases, there may be costs for acquiring data required by equity crowdfunding platform. Other costs include sales and marketing costs, which keep increasing to target larger audience.

\subsubsection{Revenue Stream}

Revenue streams describe the incoming money stream of the crowdfunding platform by offering values to its target segments. It outlines the activities and pricing of the offered values with which a company improves its revenues. The revenue stream for crowdfunding platforms are as follow:

a) As crowdfunding platform, the revenue streams are based on project commissions of successfully funded projects. It mostly relies on commission revenues.

b) Other sources of revenue included the consultation and service charge. By providing additional service to entrepreneur that struggling to do some of the process, both entities gain benefits. It's a win-win situation whereby the entrepreneur problems are being solved and the platform receives money from it. Having the idea to get additional income for company is best to make it profitable in long run.

\subsubsection{Risk Management}

Crowdfunding platform organization should do screening of the entrepreneur to diligently understand their background and capability. Thus, a strong project needs to consider a well plan strategy by entrepreneur to ensure a successful campaign. This finding is highly relevant with other finding by [28] which discussed the possibility of crowdfunding risks and the importance to coming up with a solution that can mitigate the risk including the inclusion of blockchain technology. In [29], also stated risk assessment in digital environment including transparency to increase the trust between the related parties.

\section{CONCLUSION}

The exposure of crowdfunding especially in Malaysia is still relatively low. The lack of proper business model has lead to unclear and ineffective management of crowdfunding. Thus, there is a need to propose a business model that will help the crowdfunding platform company specifically and entrepreneur and funders generally to understand how crowdfunding works. This paper thus proposed business model canvas for crowdfunding implementation. There are total of 10 building blocks introduced in the BMC namely partner network, core competency, key resources, value proposition, customer relationship, distribution channel, customer segments, cost structure, revenue stream and risk management. The building blocks takes into consideration the technological innovativeness enabling ubiquitous communications changing to adapt to rapid business environment and to provide efficiency to organization and provide value to consumer.

\section{ACKNOWLEDGEMENTS}

The authors would like to thank to Research Management Institute, Universiti Teknologi MARA, Malaysia for their funding support under LESTARI Research Grant with project code 600-IRMI/Dana KCM 5/3LESTARI (157/2017). The paper also acknowledged the support given by Crowd Business and Innovation Research Interest Group, Faculty of Computer and Mathematical Sciences, UiTM Shah Alam. 


\section{REFERENCES}

[1] A. Cosh, et al., “Outside Entrepreneurial Capital,” Economic Journal, vol. 119, pp. 1494-1533, 2009.

[2] N. Ibrahim and Verliyantina, "The Model of Crowdfunding to Support Small and Micro Business in Indonesia Through a Web-Based Platform," Procedia Economics and Finance, vol. 4, pp. 390-397, 2012.

[3] A. Abdullah, "Crowdfunding As An Emerging Fundraising Tool: With Special Reference to The Malaysian Regulatory Framework," Islam and Civilisational Renewal, vol. 7(1), pp. 98-119, 2016.

[4] Z. Zakariah, et al., "Crowdsourcing: The Trend of Prior Studies," $4^{\text {th }}$ International Conference on Artificial Intelligence with Applications in Engineering and Technology, December 2014.

[5] A. Osterwalder, "The Business Model Ontology A Proposition In A Design," Science Approach, pp. 169-172, 2004.

[6] M. Morris, et al., (2005a). “The entrepreneur's business model: Toward a unified perspective,” Journal of Business Research, vol. 58(6), pp. 726-735, 2005.

[7] A. Osterwalder, et al., "Clarifying business models: origins, present, and future of the concept," Communications of the Association for Information Systems, vol. 15(1), pp. 1-43, 2005.

[8] C. Baden-Fuller and M. S. Morgan, "Business models as models," Long Range Planning, vol. 43(2-3), pp. 156-171, 2010.

[9] D. J. Teece, (2010). "Business models, business strategy and innovation," Long Range Planning, vol. 43(2-3), pp. 172-194, 2010.

[10] C. Zott, and R. Amit, (2010). "Business Model Design : An Activity System Perspective," Long Range Planning, vol. 43(2-3), pp. 216-226, 2010.

[11] P. J. Williamson, “Cost Innovation: Preparing for a 'Value-for-Money’ Revolution,” Long Range Planning, vol. 43, pp. 343-353, 2010.

[12] A. Gambardella, and A. M. Mcgahan, "Business-Model Innovation: General Purpose Technologies and Their Implications for Industry Structure,” Long Range Planning, vol. 43, pp. 262-271, 2010.

[13] H. Itami, and K. Nishino, "Killing two birds with one Stone, Profit for Now and Learning for the Future," Long Range Planning, vol. 43, pp. 364-369, 2010.

[14] M. Yunus, et al., "Building social business models: lessons from the Grameen experience," Long Range Planning, vol. 43, pp. 308-325, (2010).

[15] R. Casadesus-Masanell and J. E. Ricart, "From Strategy to Business Models and on to Tactics," Long Range Planning, vol. 43, pp. 195-215, 2010.

[16] B. Demil and X. Lecocq, "Business Model Evolution: In Search of Dynamic Consistency," Long Range Planning, vol. 43, pp. 227-246, 2010.

[17] V. Sabatier et al., "From Business model to Business model portfolio in the European biopharmaceutical industry, Long Range Planning, vol. 43 (2-3), pp. 431-447, 2010.

[18] C. Lee et al., "Keeping abreast of technology-driven business model evolution: A dynamic patent analysis approach," Technology Analysis and Strategic Management, vol. 25(5), pp. 487-505, 2013. https://doi.org/10.1080/09537325.2013.785513

[19] C. Zott et al., (2011). "The Business Model: Recent Developments and Future Research the Business Model: Recent Developments and Future Research the Business Model," Recent Developments and Future Research, Retrieved from http://ssrn.com/1674384, 2011.

[20] G. Burtch et al., (2012). "An empirical examination of cultural biases in interpersonal economic exchange," ICIS, vol. 4, pp. 3329-3346, 2012.

[21] N. Nordin et al., "Crowdfunding: A Promising Alternative To Turn Dreams Into Reality," Journal of Business Research, vol. 6(1), pp. 86-98, 2017.

[22] A. Juva, "Crowdfunding as an alternative method of finance for Finnish start-ups," Business Finance, pp. 111-114, 2017.

[23] N. Zakaria et al., “Assessment of Crowdsourcing Task Multidimensional Relationship Model through Application Prototype," Indonesian Journal of Electrical Engineering and Computer Science, vol. 12(1), pp. 378-385, 2018.

[24] N. Arshad et al., "Micro Sourcing Strategic Framework for Low Income Group", International Journal of Advanced Computer Science and Applications (IJACSA), U.S, 2013.

[25] Z. Zakariah et al., "Crowdsourcing to Uplift the Lifestyle of Low-Income Community," American Scientific Publishers, vol. 22(5-6), 2016.

[26] G. K. C. Ahlers et al., "Signaling in Equity Crowdfunding," Entrepreneurship Theory and Practice, vol. 39(4), pp. 955-980, 2015.

[27] Z. Zakariah et al., "Crowdsourcing Business Model for Low Income Community: Conceptual Model," SAI Computing Conference 2016, July 13-15, 2016, London, UK.

[28] M. N. Saadar et al., "Blockchain-based Crowdfunding Systems," Indonesian Journal of Electrical Engineering and Computer Science, vol. 15(1), pp. 409-413, 2019.

[29] N. A. N. M. Idros et al., "The Use of Expert Review in Component Development for Customer Satisfaction towards e-hailing," Indonesian Journal of Electrical Engineering and Computer Science, Vol 17(1), pp. 347-356, 2020. 